\title{
THE USE OF TUNED MASS DAMPERS FOR REDUCING STRUCTURAL VULNERABILITIES DURING THE SIDE MOVEMENTS OF BUILDINGS WITH REINFORCED CONCRETE FRAMES
}

RECE Laurentiu - Prof. Eng., PhD.Technical University of Civil Engineering, Bucharest EZZAKI Naima - Doctorand student at Doctoral School, Technical University ofCivil Engineering of Bucarest

STOICA Daniel - Assoc. Prof. Eng., PhD.Technical University of Civil Engineering, Bucharest

JEFLEA Victor Florin - Assoc. Prof. Eng., Ph.D. Ovidius University of Constanţa

\begin{abstract}
The present article aims to point out, with the help of a comparative research, the efficiency of tuned mass dampers, modern variants of consolidation ensuring seismic structural safety, used for buildings with a reinforced concrete structure, designed and produced according to the new codes. Case studies were based on structural computations in the linear elastic field using the ETABS program.
\end{abstract}

Keywords: TMD, vulnerability, earthquake, damper

\section{INTRODUCTION}

The TMD (Tuned Mass Damper) is extremely efficient in monitoring the vibrations of a structure; it is made of a mass, a viscous damper and a spring attached to a specific structure, in order to reduce the wind and earthquake induced vibrations. The frequency and damping of these systems are tuned, so that, when the structure resonates at a certain frequency (period) the TMD oscillates with the same period, but not in phase with the structure. Consequently, the energy is transmitted from the primary system (structure) to the secondary one (TMD) and dissipated into the damper. The main purpose of this paper is to observe the efficiency of TMD for different building structures and rise. In order to obtain responses three shapes of layouts were used: circular, square and rectangular, each one with two type of structures (RC frames and dual RC) for 5, 10, 15, 20, 25, 30, 35 and 40 levels. 
ROMANIAN JOURNAL

OF TRANSPORT INFRASTRUCTURE

RECE Laurentiu, EZZAKI Naima, STOICA Daniel , JEFLEA Victor Florin

The use of tuned mass dampers for reducing structural vulnerabilities during the side movements of buildings with reinforced concrete frames

\section{THE USE OF TUNED MASS DAMPERS AROUND THE WORLD}

The first tuned mass dampers were proposed by Fhram in 1909, their purpose being to reduce vibrations produced by monotonous harmonic forces. He noticed that, if a secondary system made of a mass, a damper and a spring is attached to a primary system and its period is tuned in with the basic period of the primary system, the result is a significant decrease of the dynamic response.

The first building equipped with a tuned mass damper is Centerpoint Tower in Sydney, Australia. Its structure was completed in 1981 and it is $309 \mathrm{~m}$ high.

One Wall Center, also known as the Sheraton Vancouver Wall Center Hotel, has 48 levels and a height of $158 \mathrm{~m}$. In order to prevent potential harmonic vibrations caused by the strong wind, the tower was equipped with a tuned water damper. This system was placed on the top level and is made of two tanks with the capacity of 227,0001 . These tanks were designed to ensure that the harmonic frequency of water movement and the harmonic movement are balanced.

Taipei 101, also known as Taipei World Financial Center was the tallest building from 2004 until the erection of Burj Khalifa. It has 101 levels and a height of $508 \mathrm{~m}$.

Its civil engineers designed a steel pendulum weighing 660 tons to act as a tuned mass damper. Suspended between the $92^{\text {nd }}$ and the $87^{\text {th }} l e v e l s$, the pendulum was set to move out of phase with the structure, to stop the effect of wind gusts. The pendulum with a length of $5.5 \mathrm{~m}$ is made of 41 circular steel plates, $125 \mathrm{~mm}$ high.

Two more tuned mass dampers, weighing 6 tons, are mounted at the top of the spire and they help to prevent the damage caused by high wind loads.

The tuned mass damper was also used in engineering works such as the Akashi Kaikyo bridge. With a total length of $3911 \mathrm{~m}$, the bridge has pendulums designed to operate at the resonant frequency of the bridge, thus absorbing the forces given by wind and earthquake loads.

\section{THEORETICAL CONCEPTS AND PRINCIPLES}

Structural vibrations are reduced with TMD inside a structure, according to the principle of vibration energy transfer into the TMD for dissipation. Thus, the TMD frequency is in tune with a certain frequency of the structure. When this point is reached, the TMD will resonate, out of tune with the movement of the structure. 
ROMANIAN JOURNAL

OF TRANSPORT INFRASTRUCTURE

RECE Laurentiu, EZZAKI Naima, STOICA Daniel, JEFLEA Victor Florin

The use of tuned mass dampers for reducing structural vulnerabilities during the side movements of buildings with reinforced concrete frames

In comparison with other dissipation methods, the use of TMDs requires the use of a mass and of wide movements. The way in which the TMD is mounted and set is extremely important in the system design. Usually the mass of the damper system is in the range of $0.25 \ldots 1 \%$ of the building mass in the basic vibration mode.

In certain cases, the limited space does not allow the use of a classic tuned mass damper. This limitation led to the creation of alternative systems, such as the multi-stage pendulum, the reversed pendulum, or hydrostatic bearings. The systems are usually tuned with the help of spired springs or pneumatic springs with a variable rigidity.
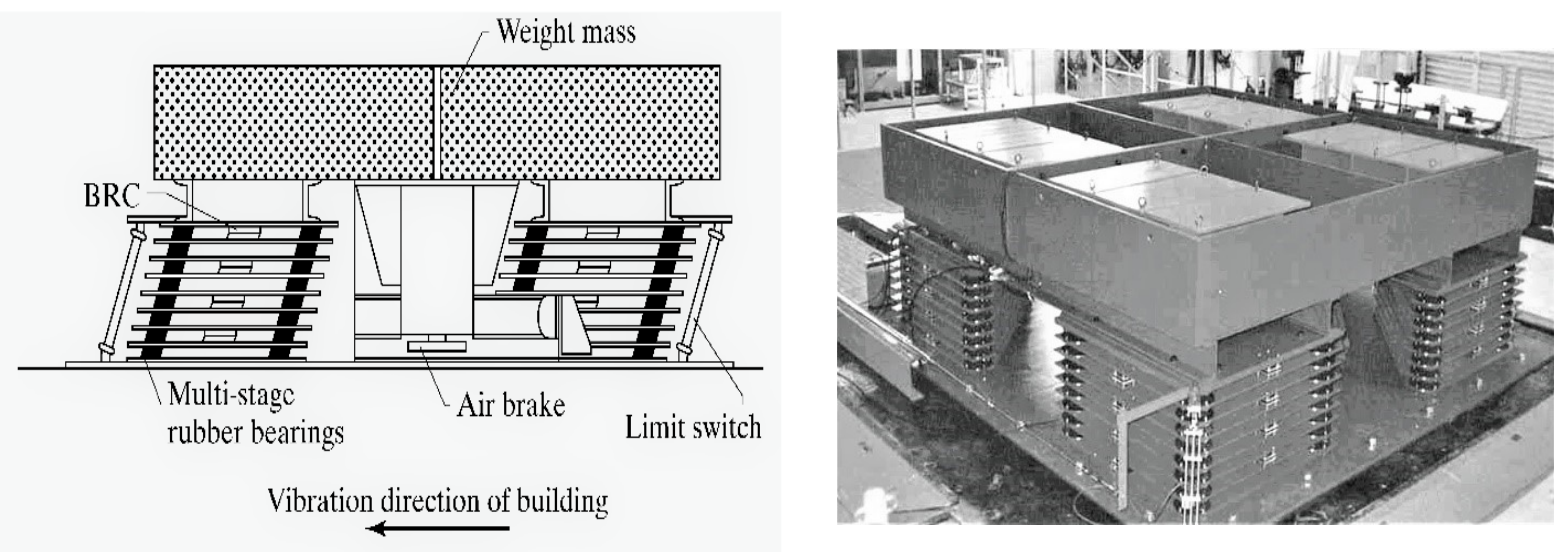

Figure 1. Example of a system with tuned mass (Courtesy of J. Connor)

Problems arising due to space limitation can be solved if a pendulum is used:

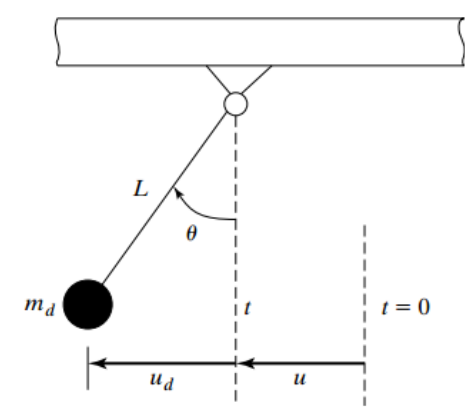

Existing system

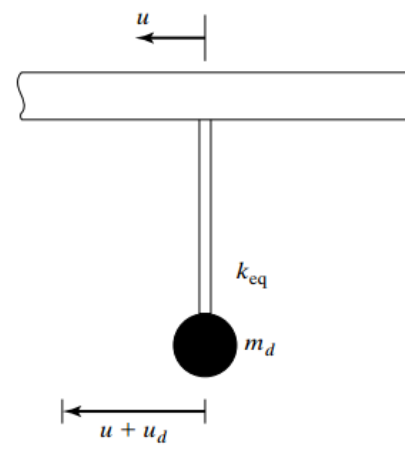

Equivalent system

Figure 2. Diagram of a TMD pendulum

The horizontal movement equation is:

$$
T \sin \theta+\frac{W_{d}}{g}\left(\ddot{u}+\ddot{u}_{d}\right)=0
$$


ROMANIAN JOURNAL

OF TRANSPORT INFRASTRUCTURE

RECE Laurentiu, EZZAKI Naima, STOICA Daniel, JEFLEA Victor Florin

The use of tuned mass dampers for reducing structural vulnerabilities during the side movements of buildings with reinforced concrete frames

where $\mathrm{T}$ is the cable tension; $\mathrm{u}(\mathrm{t})$ - the structure movement; $\mathrm{u}_{\mathrm{d}} \mathrm{t}-$ the movement of the pendulum mass; $\mathrm{W}_{\mathrm{d}}$ - the pendulum weight; $\mathrm{m}_{\mathrm{d}}-$ the pendulum mass:

$$
u_{d}=L \sin \theta \cong L \theta ; \quad T \cong W_{d}
$$

Therefore:

$$
m_{d} \ddot{u}_{d}+\frac{W_{d}}{L} u_{d}=-m_{d} \ddot{u}
$$

So that the resulting equivalent shear rigidity is:

$$
k_{e q}=\frac{W_{d}}{L}
$$

The pendulum pulsation is:

$$
\omega_{d}^{2}=\frac{k_{e q}}{m_{d}}=\frac{g}{L}
$$

Whereby the resulting period is:

$$
T_{d}=2 \pi \sqrt{\frac{L}{g}}
$$

The only major limitation related to the use of a pendulum is that the pendulum must be longer than the height of a storey. This issue can be solved using the diagram below:

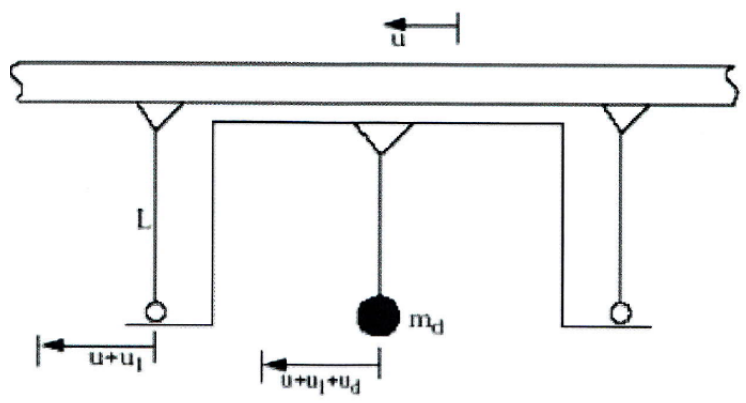

Figure 3. Solving the limitation related to the excessive length of a pendulum

The rigid inner joint amplifies the support movement and the following balance equation is valid for the pendulum:

$$
m_{d}\left(\ddot{u}+\ddot{u}_{1}+\ddot{u}_{d}\right)+\frac{W_{d}}{L} u_{d}=0
$$

The rigid joint moves in phase with the damper and has the same movement width. If $u_{1}=u_{d}$ we have: 
ROMANIAN JOURNAL

OF TRANSPORT INFRASTRUCTURE

RECE Laurentiu, EZZAKI Naima, STOICA Daniel , JEFLEA Victor Florin

The use of tuned mass dampers for reducing structural vulnerabilities during the side movements of buildings with reinforced concrete frames

$m_{d} \ddot{u}_{d}+\frac{W_{d}}{2 L} u_{d}=-\frac{m_{d}}{2} \ddot{u}$

The equivalent rigidity shows that the actual length is $2 \mathrm{~L}$. Therefore, each additional joint adds to the actual length with the value " $\mathrm{L}$ ".

\section{COMPUTATION OF TMD-TYPE SYSTEMS}

As a rule, the analysis of TMD systems involves the computation of the answer from a system with two degrees of freedom, the first one being the primary freedom degree (structure), while the second belongs to the TMD. For this purpose, we use mathematical procedures to derive the system response with two degrees of freedom, being submitted to harmonic frequency stimuli. The following section presents these responses for different cases.

Several basic steps must be made for the computation of a tuned mass damper-type device:

First, the location (position) of the damper must be set to coincide with the maximum amplitude point of the modal form to be monitored;

The primary system mass will be the mass on the module to be monitored with the help of the damper;

The optimal ratio of frequencies (periods) $f$ is computed and then used to determine the damper rigidity $k_{d}=m_{d} \omega_{d}^{2}$

The optimal fraction from the critical damping $\zeta_{d, o p t}$ is computed and used to determine the device damping $c_{d, o p t}=2 \zeta_{d, o p t} \omega_{d} m_{d}$

The parameter used for optimization is the "movement" and it is used to ensure the integrity of the structure and non-structural elements. However, "acceleration" can also be used for optimization in the case of heavy/sensitive equipment at high acceleration rates.

For widely used seismic applications,Villaverde (1985) suggests the use of the following equations with optimal parameters, when the ratio of the masses is based on the modal mass and the existing vector normalized in the point where the device is placed:

$f_{\text {opt }}=1$

$\zeta_{d, o p t}=\zeta+\mu$

For the same conditions, Fadek (1997) finds that: 
$f_{\text {opt }}=\frac{1}{1+\mu}\left[1-\zeta \sqrt{\frac{\mu}{1+\mu}}\right]$

(11)

$$
\zeta_{d, o p t}=\frac{\zeta}{1+\zeta}+\sqrt{\frac{\mu}{1+\mu}}
$$

Note:

Devices of this type are efficient in low damping seismic applications $\zeta=$ 0.022 . For structures with $\zeta=0.05$, damping, they are not too efficient because the ratio of the masses is too big. Also, they are not efficient in the case of highly rigid structures with $0.1 \mathrm{~s}-0.2 \mathrm{~s}$ periods.

Table 1. Optimal parameters.

\begin{tabular}{|c|c|c|c|c|c|c|}
\hline System & $\begin{array}{l}\text { Excitat- } \\
\text { ion type }\end{array}$ & $\begin{array}{l}\text { Excitat- } \\
\text { ion } \\
\text { applied }\end{array}$ & $\begin{array}{l}\text { Optimized } \\
\text { parameter }\end{array}$ & $\begin{array}{c}\text { The } \\
\text { optimal } \\
\text { freque } \\
\text { ncy } \\
\text { ratio } \\
\boldsymbol{f}_{\text {opt }} \\
\end{array}$ & $\begin{array}{c}\text { Optimal } \\
\text { damping } \\
\zeta_{d, o p t}\end{array}$ & $\begin{array}{c}\text { Maximum } \\
\text { optimized } \\
\text { response } \\
\text { of the } \\
\text { structure } \\
\boldsymbol{u}_{\boldsymbol{r}} \\
\end{array}$ \\
\hline $\begin{array}{l}\text { Damped } \\
\text { system, } \\
\text { TMD } \\
\text { damped }\end{array}$ & \multirow{3}{*}{ 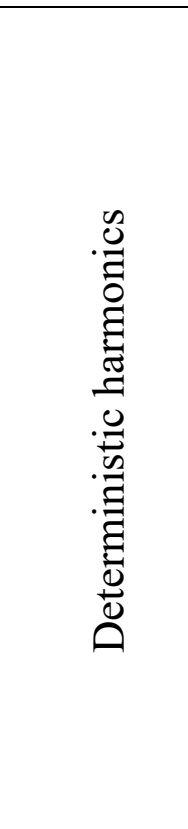 } & $\begin{array}{l}\text { Primary } \\
\text { mass and } \\
\text { base }\end{array}$ & $\begin{array}{l}\text { Movement } \\
\text { of the } \\
\text { primary } \\
\text { mass }\end{array}$ & - & - & $\frac{\left(p_{0}+m a_{0}\right) / h}{\sqrt{2 \zeta\left(1-\zeta^{2}\right)}}$ \\
\hline $\begin{array}{c}\text { Undampe } \\
\text { d system, } \\
\text { TMD } \\
\text { undampe } \\
\text { d }\end{array}$ & & $\begin{array}{l}\text { Primary } \\
\text { mass }\end{array}$ & $\begin{array}{l}\text { Movement } \\
\text { of the } \\
\text { primary } \\
\text { mass }\end{array}$ & - & - & - \\
\hline $\begin{array}{c}\text { Undampe } \\
\text { d system, } \\
\text { TMD } \\
\text { damped }\end{array}$ & & $\begin{array}{l}\text { Primary } \\
\text { mass }\end{array}$ & $\begin{array}{l}\text { Movement } \\
\text { of the } \\
\text { primary } \\
\text { mass }\end{array}$ & $\frac{1}{1+\mu}$ & $\sqrt{\frac{3 \mu}{8(1+\mu)}}$ & $\frac{p_{0}}{k} \sqrt{1+\frac{2}{\mu}}$ \\
\hline
\end{tabular}


ROMANIAN JOURNAL

OF TRANSPORT INFRASTRUCTURE

RECE Laurentiu, EZZAKI Naima, STOICA Daniel, JEFLEA Victor Florin

The use of tuned mass dampers for reducing structural vulnerabilities during the side movements of buildings with reinforced concrete frames

\begin{tabular}{|c|c|c|c|c|c|c|}
\hline $\begin{array}{c}\text { Undampe } \\
\text { d system, } \\
\text { TMD } \\
\text { damped }\end{array}$ & & $\begin{array}{l}\text { Primary } \\
\text { mass }\end{array}$ & $\begin{array}{l}\text { Acceleratio } \\
\text { nof the } \\
\text { primary } \\
\text { mass }\end{array}$ & $\frac{1}{1+\mu}$ & $\sqrt{\frac{3 \mu}{8(1+\mu / 2)}}$ & $\frac{p_{0}}{k} \sqrt{\frac{2}{\mu(1+\mu)}}$ \\
\hline $\begin{array}{c}\text { Undampe } \\
\text { d system, } \\
\text { TMD } \\
\text { damped }\end{array}$ & & Base & $\begin{array}{l}\text { Movement } \\
\text { of the } \\
\text { primary } \\
\text { mass }\end{array}$ & $\frac{\sqrt{1-\mu / 2}}{1+\mu}$ & $\sqrt{\frac{3 \mu}{8(1+\mu)(1}}$ & $\begin{array}{l}\frac{m a_{0}}{k}(1 \\
+\mu) \sqrt{\frac{2}{\mu}}\end{array}$ \\
\hline $\begin{array}{c}\text { Undampe } \\
\text { d system, } \\
\text { TMD } \\
\text { damped }\end{array}$ & & Base & $\begin{array}{l}\text { Acceleratio } \\
\mathrm{n} \\
\text { of the } \\
\text { primary } \\
\text { mass }\end{array}$ & $\frac{1}{1+\mu}$ & $\sqrt{\frac{3 \mu}{8(1+\mu)}}$ & $\frac{m a_{0}}{k} \sqrt{1+\frac{2}{\mu}}$ \\
\hline $\begin{array}{c}\text { Undampe } \\
\text { d system, } \\
\text { TMD } \\
\text { damped }\end{array}$ & 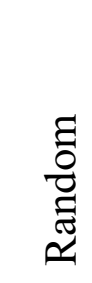 & $\begin{array}{l}\text { Primary } \\
\text { mass }\end{array}$ & $\begin{array}{l}\text { Movement } \\
\text { of the } \\
\text { primary } \\
\text { mass }\end{array}$ & $\frac{\sqrt{1+\mu / 2}}{1+\mu}$ & $\sqrt{\frac{\mu\left(1+\frac{3}{4}\right.}{4(1+\mu)(1}}$ & $\frac{p_{0}}{k} \sqrt{\frac{\left(1+\frac{3 \mu}{4}\right)}{\mu(1+\mu)}}$ \\
\hline $\begin{array}{c}\text { Undampe } \\
\text { d system, } \\
\text { TMD } \\
\text { damped }\end{array}$ & & Base & $\begin{array}{l}\text { Movement } \\
\text { of the } \\
\text { primary } \\
\text { mass }\end{array}$ & $\frac{\sqrt{1-\mu / 2}}{1+\mu}$ & $\sqrt{\frac{\mu\left(1-\frac{\mu}{4}\right.}{4(1+\mu)(1}}$ & $\frac{p_{0}}{k} \sqrt{\frac{\left(1+\frac{3 \mu}{4}\right)}{\mu(1+\mu)}}$ \\
\hline $\begin{array}{c}\text { Damped } \\
\text { system, } \\
\text { TM } \\
\text { damped }\end{array}$ & 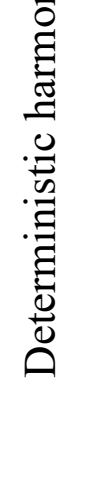 & $\begin{array}{l}\text { Primary } \\
\text { mass }\end{array}$ & $\begin{array}{l}\text { Movement } \\
\text { of the } \\
\text { primary } \\
\text { mass }\end{array}$ & $\begin{array}{l}\frac{1}{1+\mu} \\
-(0.241 \\
+1.7 \mu \\
\left.-2.6 \mu^{2}\right) \\
-(1.0 \\
-1.9 \mu \\
\left.+\mu^{2}\right) \zeta^{2}\end{array}$ & $\begin{array}{l}\sqrt{\frac{3 \mu}{8+(1+\mu)}} \\
+(0.13 \\
+0.12 \mu \\
\left.+0.4 \mu^{2}\right) \zeta \\
-(0.01 \\
+0.9 \mu \\
\left.+3 \mu^{2}\right) \zeta^{2}\end{array}$ & \\
\hline
\end{tabular}


ROMANIAN JOURNAL

OF TRANSPORT INFRASTRUCTURE

RECE Laurentiu, EZZAKI Naima, STOICA Daniel, JEFLEA Victor Florin

The use of tuned mass dampers for reducing structural vulnerabilities during the side movements of buildings with reinforced concrete frames

\section{CASE STUDIES I}

Considering the above theoretical information, the following section presents just several data from all case studies for RC structures with different plane shapes and a height regime for a structure P+39E (40 levels). The height for each floor was set at $3 \mathrm{~m}$. Structures are classified as follows:

Function of the structural system:

Structural system with reinforced Function of the plane form:

concrete frames;

Circular

Dual structural system (reinforced

Square

concrete frames and walls)

Rectangular
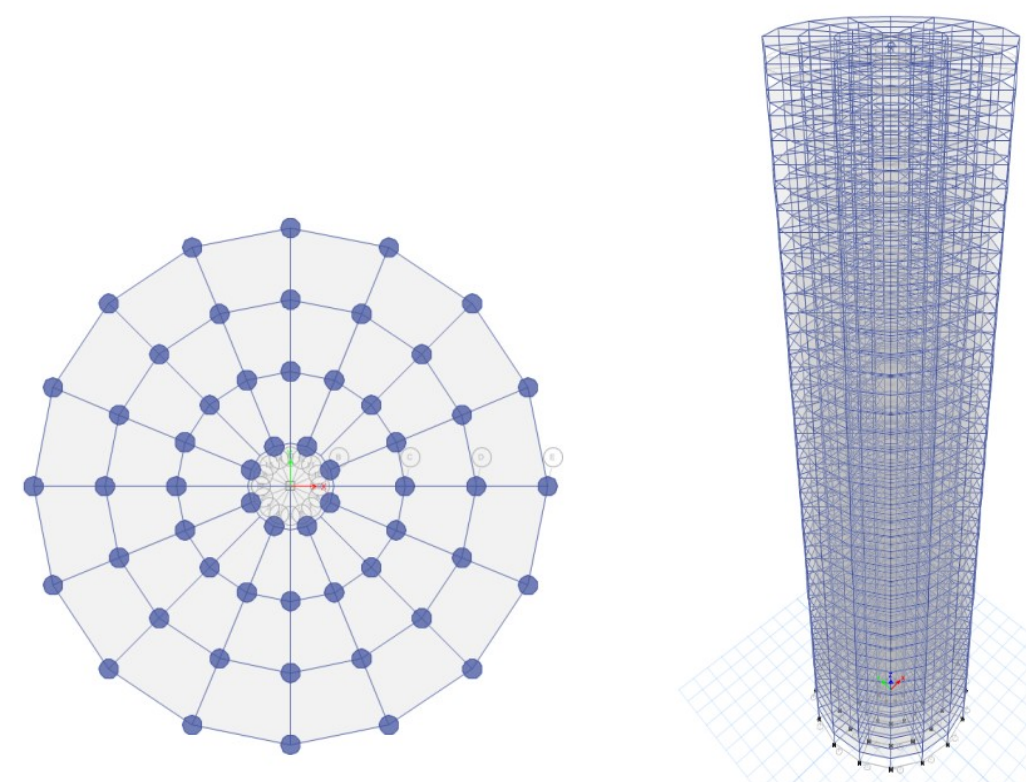

Figure 4. Structure with circular reinforced concrete frames - plane and elevation 
ROMANIAN JOURNAL

OF TRANSPORT INFRASTRUCTURE

RECE Laurentiu, EZZAKI Naima, STOICA Daniel, JEFLEA Victor Florin

The use of tuned mass dampers for reducing structural vulnerabilities during the side movements of buildings with reinforced concrete frames
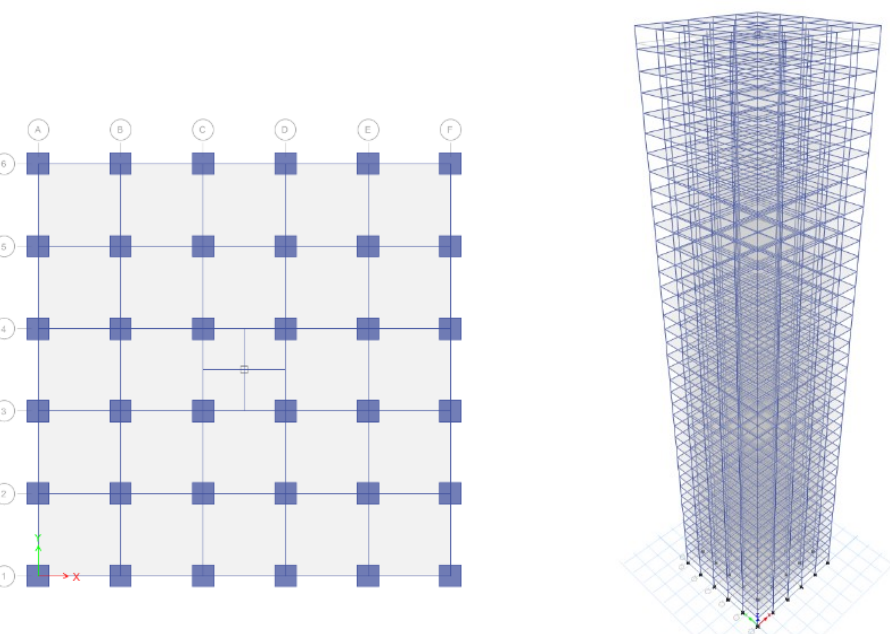

Figure 5. Structure with square reinforced concrete frames - plane and elevation
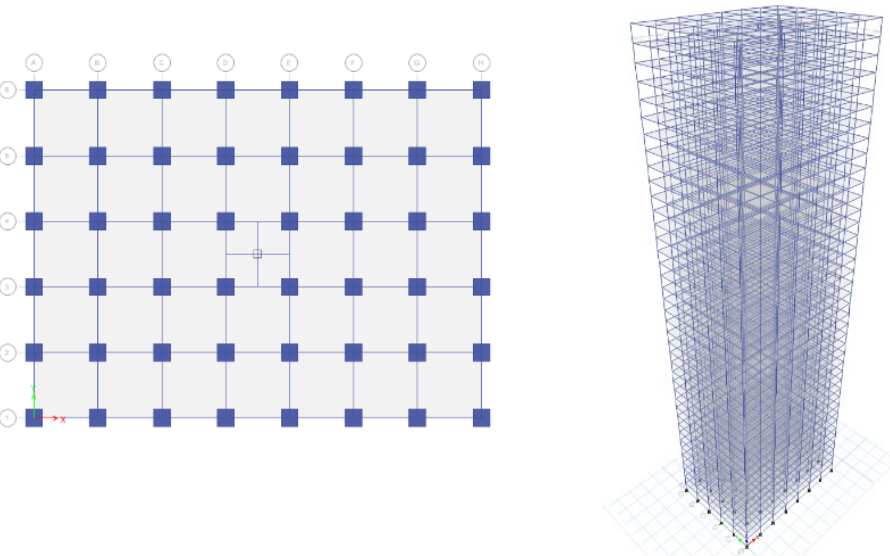

Figure 6. Structure with rectangular reinforced concrete frames - plane and elevation 
ROMANIAN JOURNAL

OF TRANSPORT INFRASTRUCTURE

RECE Laurentiu, EZZAKI Naima, STOICA Daniel, JEFLEA Victor Florin

The use of tuned mass dampers for reducing structural vulnerabilities during the side movements of buildings with reinforced concrete frames
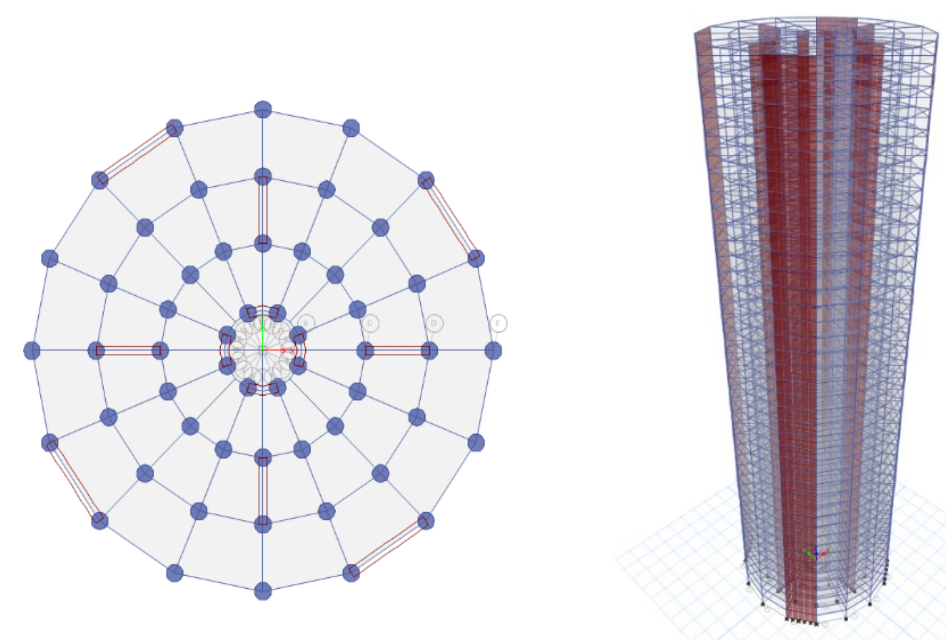

Figure 7. Dual reinforced concrete structure with a circular shape - plane and elevation
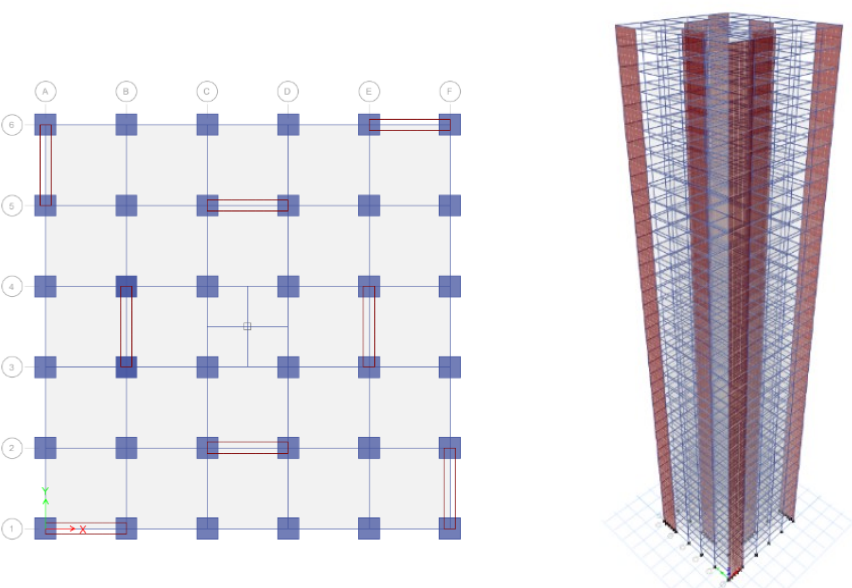

Figure 8. Dual reinforced concrete structure with a square shape - plane and elevation 

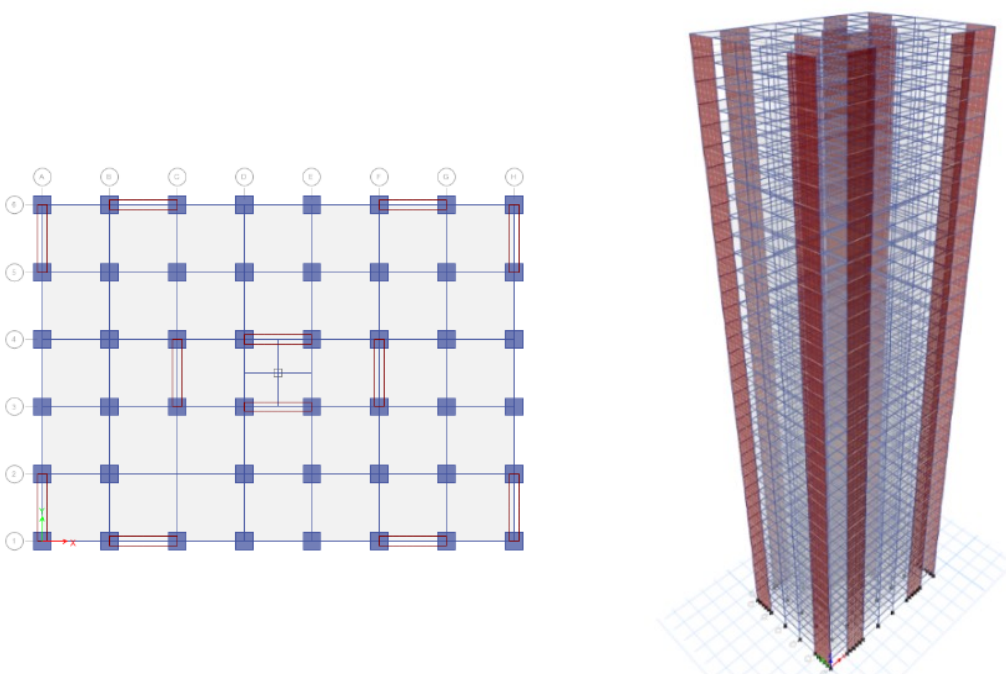

Figure 9. Dual reinforced concrete structure with a rectangular shape - plane and elevation

In order to minimize the number of variables and better emphasize the use of TMDs, the distance between axes is $5 \mathrm{~m}$. The concrete is class $\mathrm{C} 30 / 37$ with an elasticity module of $\mathrm{E}=33000 \mathrm{~N} / \mathrm{mm}^{2}$. The dimensions of the structural elements under focus are the following:

Table 2. The dimensions of the structural elements.

\begin{tabular}{|c|l|c|c|c|c|c|}
\hline \multirow{2}{*}{ Structure type } & \multicolumn{1}{|c|}{$\begin{array}{c}\text { Plane } \\
\text { shape }\end{array}$} & $\begin{array}{c}\text { Side } \\
\text { poles } \\
{[\mathbf{c m}]}\end{array}$ & $\begin{array}{c}\text { Longitudinal } \\
\text { beam } \\
{[\mathbf{c m}]}\end{array}$ & $\begin{array}{c}\text { Cross } \\
\text { beam } \\
{[\mathbf{c m}]}\end{array}$ & $\begin{array}{c}\text { Radial } \\
\text { beam } \\
{[\mathbf{c m}]}\end{array}$ & $\begin{array}{c}\text { Wall } \\
\text { thickness } \\
{[\mathbf{c m}]}\end{array}$ \\
\hline \multirow{2}{*}{$\begin{array}{c}\text { Frame } \\
\text { structure }\end{array}$} & Circular & 130 & - & - & $35 \times 80$ & - \\
\cline { 2 - 7 } & Square & 130 & $35 \times 80$ & $35 \times 75$ & - & - \\
\cline { 2 - 7 } & Rectangular & 130 & $35 \times 80$ & $35 \times 80$ & - & - \\
\hline \multirow{3}{*}{ Dual structure } & Circular & 130 & - & - & $35 \times 80$ & 70 \\
\cline { 2 - 7 } & Square & 130 & $35 \times 80$ & $35 \times 80$ & - & 70 \\
\cline { 2 - 7 } & Rectangular & 130 & $35 \times 80$ & $35 \times 80$ & - & 70 \\
\hline
\end{tabular}

The following design projection was used for the analysis with response projections: 
ROMANIAN JOURNAL

OF TRANSPORT INFRASTRUCTURE

RECE Laurentiu, EZZAKI Naima, STOICA Daniel , JEFLEA Victor Florin

The use of tuned mass dampers for reducing structural vulnerabilities during the side movements of buildings with reinforced concrete frames

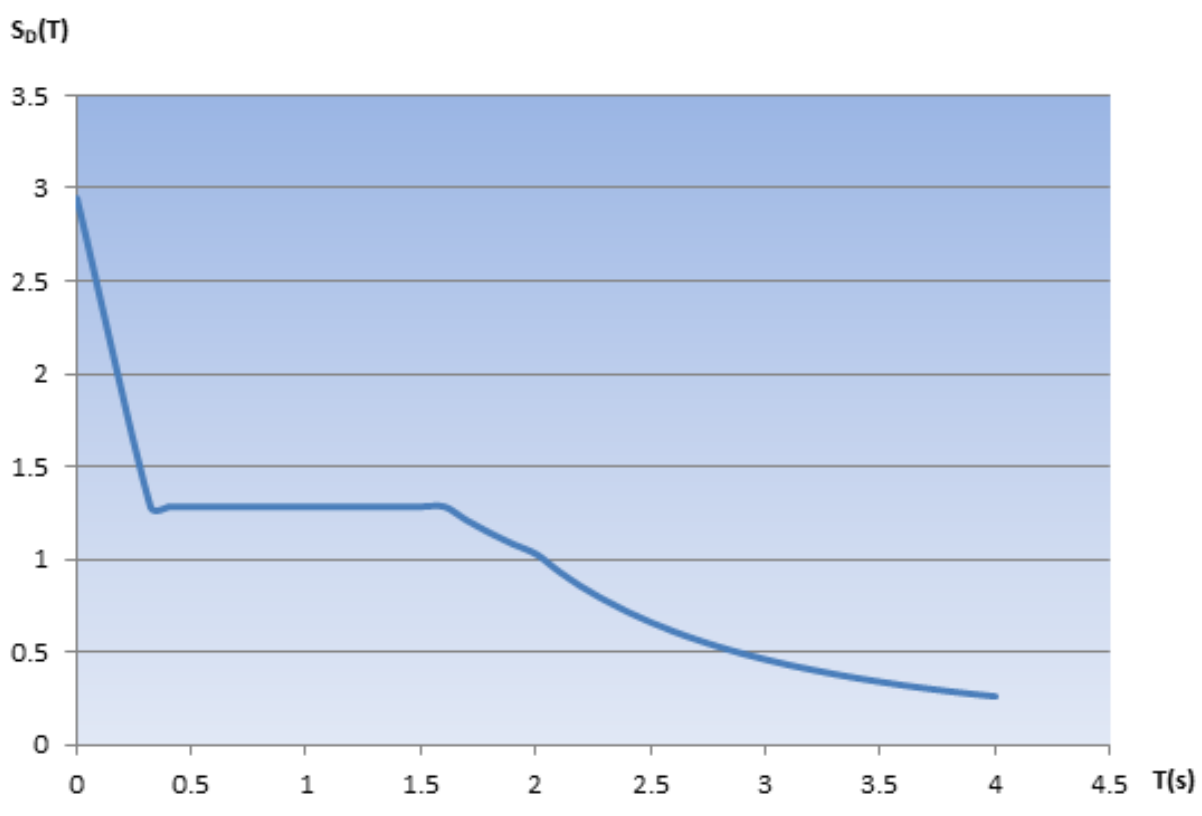

Figure.10. Design spectra for $\mathrm{a}_{\mathrm{g}}=0.30 \mathrm{~g}$

In order to set the size of the tuned mass dampers the following steps were considered:

First, the location (position) of the damper was set to coincide with the maximum amplitude point of the modal shape to be monitored. The mass of the primary system will be the mass applied on the module, to be monitored with the damper. The higher the ratio of the masses $\mu$ the lower the response (the damper is less affected by the tuning). Therefore, the highest possible ratio is chosen.

The optimal ratio of frequencies (periods) $\mathrm{F}$ is determined, then used to compute the damper rigidity $k_{d}=m_{d} \omega_{d}^{2}$

The optimal fraction of the critical damping $\zeta_{d, o p t}$ is determined, then used to compute the device damping, $c_{d, o p t}=2 \zeta_{d, o p t} \omega_{d} m_{d}$

\section{System modeling with the tuned mass:}

As previously described, the Tuned Mass Damper must be positioned in the maximum amplitude point of the mode to be monitored. In the cases under study, this point can be any point on the floor of the last storey.

The TMD system is modeled with the help of a friction pendulum-type insulator, in order to simulate the physical movement of the TMD, while for the 


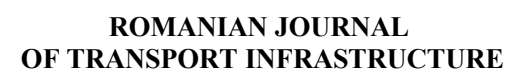

RECE Laurentiu, EZZAKI Naima, STOICA Daniel, JEFLEA Victor Florin

The use of tuned mass dampers for reducing structural vulnerabilities during the side movements of buildings with reinforced concrete frames

damping part a viscous damper-type link was used. Two links with these names are included in the program, with characteristics determined by computation.

The modeling must consider the link design mode (upwards) in order to correctly define the damping movement. For good operation, the point on the floor of the last storey will be set in its center, while the free one will be set on the same vertical axis, at an equal distance to the pendulum length.

The free point must also support masses on the main directions; these masses are determined through TMD computation.

$\mu$ - ratio of the masses;

$\zeta$ - fraction of the critical damping;

$\mathrm{m}_{\text {mod.1 }}$ - mass moved on the vibration mode 1 ;

$\mathrm{m}_{\text {mod.2 }}$ - mass moved on the vibration mode 2 .

$m_{d}=\mu \times m_{m o d, 1}$

$f_{\text {opt }}=\frac{1}{1+\mu}-\left(0.241+1.7 \mu-2.6 \mu^{2}\right) \zeta-\left(1.0-1.9 \mu+\mu^{2}\right)$

$\zeta_{d, o p t}=\sqrt{\frac{3 \mu}{8+(1+\mu)}}+\left(0.13+0.12 \mu+0.4 \mu^{2}\right) \zeta-\left(0.01+0.9 \mu+3 \mu^{2}\right) \zeta^{2}$

$f_{d}=f_{\text {mod, } 1} \times f_{\text {opt }}$

$T_{d}=\frac{1}{f_{d}}$

$\omega^{2}=2 \pi f_{d}$

$k_{d}=m_{d} \omega_{d}^{2}$

$c_{d, o p t}=2 \zeta_{d, o p t} \omega_{d} m_{d}$

$L_{\text {pendul }}=\frac{T_{d}^{2} \times g}{4 \pi^{2}}$

For the structures included in the analysis, the TMD characteristics are the following:

Table 3.TMD characteristics.

\begin{tabular}{|c|l|c|c|c|c|c|}
\hline \multirow{2}{*}{$\begin{array}{c}\text { Structure } \\
\text { type }\end{array}$} & Plane shape & $\begin{array}{c}\text { Pendulum } \\
\text { length } \\
{[\mathbf{m}]}\end{array}$ & $\begin{array}{c}\text { Rigidity } \\
\mathbf{k}_{\mathbf{d}} \\
{[\mathbf{k N / m}]}\end{array}$ & $\begin{array}{c}\text { Device } \\
\text { dampingc } \\
{[\mathbf{k N} / \mathbf{s}]}\end{array}$ & $\begin{array}{c}\text { Mode } \\
\mathbf{1} \text { mass } \\
{[\mathbf{k N}]}\end{array}$ & $\begin{array}{c}\text { Mode 2 } \\
\mathbf{m a s s} \\
{[\mathbf{k N}]}\end{array}$ \\
\hline \multirow{2}{*}{$\begin{array}{c}\text { Frame } \\
\text { structure }\end{array}$} & Circular & 2.35 & 22153 & 4143 & 5275 & 5275 \\
\cline { 2 - 7 } & Square & 2.3 & 15451 & 2881 & 3657 & 3657 \\
\cline { 2 - 7 } & Rectangular & 2.2 & 22325 & 4030 & 5019 & 4953 \\
\hline \multirow{2}{*}{$\begin{array}{c}\text { Dual } \\
\text { structure }\end{array}$} & Circular & 1.9 & 28238 & 4740 & 5418 & 5418 \\
\cline { 2 - 7 } & Square & 1.65 & 21450 & 3383 & 3634 & 3634 \\
\cline { 2 - 7 } & Rectangular & 1.7 & 31128 & 4934 & 5325 & 5390 \\
\hline
\end{tabular}

\section{CASE STUDIES II}


ROMANIAN JOURNAL

OF TRANSPORT INFRASTRUCTURE

RECE Laurentiu, EZZAKI Naima, STOICA Daniel , JEFLEA Victor Florin

The use of tuned mass dampers for reducing structural vulnerabilities during the side movements of buildings with reinforced concrete frames

Further on, in order to apply the notions described before, take a reinforced concrete framed structure with different height regimes: $\mathrm{P}+40 \mathrm{E}, \mathrm{P}+30 \mathrm{E}, \mathrm{P}+20 \mathrm{E}$, $\mathrm{P}+10 \mathrm{E}$. The height of each level is $3 \mathrm{~m}$. The plane shape of the structure is rectangular.
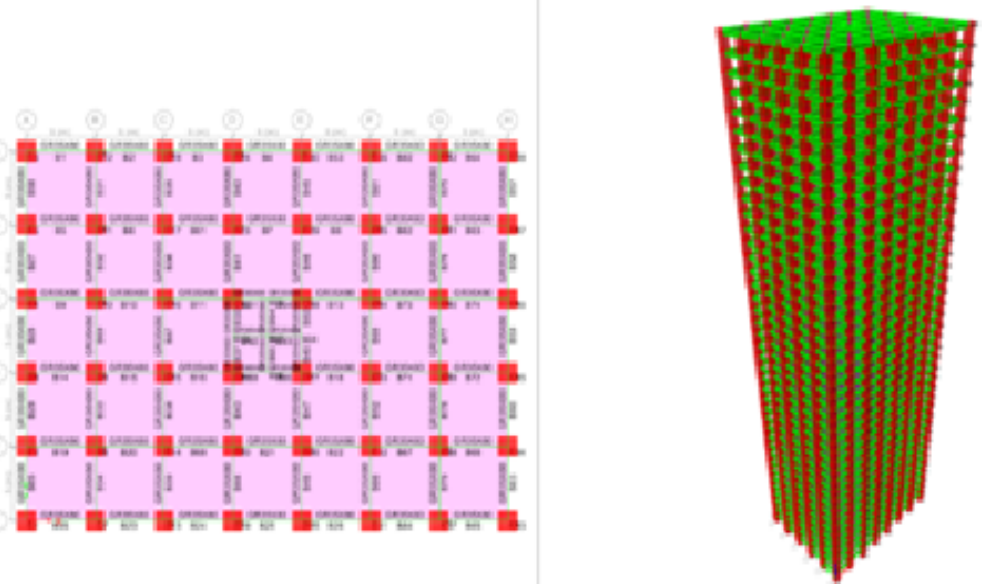

Figure 11. Reinforced concrete framed structure with a rectangular shape40 levels - plane and elevation

In order to minimize the number of variables and to better emphasize the use of TMDs, the distance between axes is $5 \mathrm{~m}$. Apart from the loads representing the load of the structure, the following ones were considered:

On existing levels: Floor and building services $-2 \mathrm{kN} / \mathrm{m}^{2}$; Separating walls -0.5 $\mathrm{kN} / \mathrm{m}^{2}$; Useful load $-2 \mathrm{kN} / \mathrm{m}^{2}$

For the top story: Useful load $2 \mathrm{kN} / \mathrm{m}^{2}$; Snow load $2 \mathrm{kN} / \mathrm{m}^{2}$; Heat insulation $3 \mathrm{kN} / \mathrm{m}^{2}$; Building services $0.5 \mathrm{kN} / \mathrm{m}^{2}$; Attic - on the border beams $-5 \mathrm{kN} / \mathrm{m}^{2}$.

The concrete used is $\mathrm{C} 20 / 25$ class with an elasticity module $\mathrm{E}=33000 \mathrm{~N} / \mathrm{mm}^{2}$. Here are the dimensions of the components:

Table 4.Dimensions of the components.

\begin{tabular}{|l|l|l|l|l|}
\hline $\begin{array}{l}\text { Structure } \\
\text { type }\end{array}$ & $\begin{array}{l}\text { Height } \\
\text { regime }\end{array}$ & $\begin{array}{c}\text { Column side } \\
(\mathbf{c m})\end{array}$ & $\begin{array}{l}\text { Longitudinal } \\
\text { beam }(\mathbf{c m})\end{array}$ & $\begin{array}{l}\text { Cross beam } \\
(\mathbf{c m})\end{array}$ \\
\hline \multirow{3}{*}{$\begin{array}{c}\text { Framed } \\
\text { structure }\end{array}$} & 40 levels & 130 & $35 \times 80$ & $35 \times 80$ \\
\cline { 2 - 5 } & 30 levels & 130 & $35 \times 80$ & $35 \times 80$ \\
\cline { 2 - 5 } & 20 levels & 100 & $35 \times 65$ & $35 \times 65$ \\
\cline { 2 - 5 } & 10 levels & 80 & $30 \times 60$ & $30 \times 60$ \\
\hline
\end{tabular}


ROMANIAN JOURNAL

OF TRANSPORT INFRASTRUCTURE

RECE Laurentiu, EZZAKI Naima, STOICA Daniel, JEFLEA Victor Florin

The use of tuned mass dampers for reducing structural vulnerabilities during the side movements of buildings with reinforced concrete frames

The following steps were considered for setting the dimensions of tuned mass dampers:

In the first phase, the location (position) of the damper is set, in order to coincide with the maximum amplitude point of the modal shape to be monitored.

The primary system mass will be the participant mass on the module, to be monitored with the damper

The higher the ratio of the masses $\mu$ the lower the response (the damper is less affected by the tuning). Therefore, the highest possible ratio is chosen.

The optimal ratio of frequencies (periods) $F$ is determined, then used to compute the damper rigidity $k_{d}=m_{d} \omega_{d}^{2}$

The optimal fraction of the critical damping $\zeta_{d, o p t}$ is determined, then used to compute the device damping, $c_{d, o p t}=2 \zeta_{d, o p t} \omega_{d} m_{d}$.

\section{Modeling of a tuned mass system:}

As previously described, the Tuned Mass Damper must be positioned in the maximum amplitude point of the mode to be monitored. In the cases under study, this point can be any point on the floor of the last storey.

The TMD system is modeled with the help of a friction pendulum-type insulator, in order to simulate the physical movement of the TMD, while for the damping part a viscous damper-type link was used. Two links with these names are included in the program, with characteristics determined by computation.

The modeling must consider the link design mode (upwards) in order to correctly define the damping movement. For good operation, the point on the floor of the last storey will be set in its center, while the free one will be set on the same vertical axis, at an equal distance to the pendulum length.

The free point must also support masses on the main directions; these masses are determined through TMD computation.

$\mu$ - ratio of the masses; $\zeta$ - fraction of the critical damping; mode. 1 - mass moved on the vibration mode 1 ; mode. 2 - mass moved on the vibration mode 2 .

$$
\begin{aligned}
& m_{d}=\mu \times m_{\text {mod }, 1} \\
& f_{\text {opt }}=\frac{1}{1+\mu}-\left(0.241+1.7 \mu-2.6 \mu^{2}\right) \zeta-\left(1.0-1.9 \mu+\mu^{2}\right)
\end{aligned}
$$

(23)

$$
\zeta_{d, o p t}=\sqrt{\frac{3 \mu}{8+(1+\mu)}}+\left(0.13+0.12 \mu+0.4 \mu^{2}\right) \zeta-\left(0.01+0.9 \mu+3 \mu^{2}\right) \zeta^{2}
$$


ROMANIAN JOURNAL

OF TRANSPORT INFRASTRUCTURE

RECE Laurentiu, EZZAKI Naima, STOICA Daniel , JEFLEA Victor Florin

The use of tuned mass dampers for reducing structural vulnerabilities during the side movements of buildings with reinforced concrete frames

$f_{d}=f_{\text {mod, }, 1} \times f_{\text {opt }}$

$T_{d}=\frac{1}{f_{d}}$

$\omega^{2}=2 \pi f_{d}$

$k_{d}=m_{d} \omega_{d}^{2}$

$c_{d, o p t}=2 \zeta_{d, o p t} \omega_{d} m_{d}$

$L_{\text {pendul }}=\frac{T_{d}{ }^{2} \times g}{4 \pi^{2}}$

For the structures included in the analysis, the TMD characteristics are the following:

Table 5.TMD characteristics.

\begin{tabular}{|c|c|c|c|c|c|c|}
\hline $\begin{array}{c}\text { Structure } \\
\text { type }\end{array}$ & $\begin{array}{c}\text { Plane } \\
\text { shape }\end{array}$ & $\begin{array}{c}\text { Pendulum } \\
\text { length }\end{array}$ & $\begin{array}{c}\text { Rigidityk } \\
{[\mathbf{k N} / \mathbf{m}]}\end{array}$ & $\begin{array}{c}\text { Device } \\
\text { damping } \\
\mathbf{c}_{\mathbf{d}}[\mathbf{k N} / \mathbf{s}]\end{array}$ & $\begin{array}{c}\text { Mode 1 } \\
\mathbf{m a s s}[\mathbf{k N}]\end{array}$ & $\begin{array}{c}\text { Mode 2 } \\
\text { mass } \\
{[\mathbf{k N}]}\end{array}$ \\
\hline \multirow{3}{*}{$\begin{array}{c}\text { Structure } \\
\text { in } \\
\text { frames }\end{array}$} & 40 levels & 2.4 & 21248 & 4032 & 5209 & 5275 \\
\cline { 2 - 7 } & 30 levels & 1.1 & 33252 & 4265 & 3276 & 3757 \\
\cline { 2 - 7 } & 20 levels & 0.7 & 28376 & 2872 & 1979 & 1987 \\
\cline { 2 - 7 } & 10 levels & 0.15 & 49765 & 2540 & 883 & 885 \\
\cline { 2 - 7 } & 5 levels & 1.7 & 31128 & 4934 & 5325 & 5390 \\
\hline
\end{tabular}

The following is a comparative presentation of the structures' behavior with and without the TMD. Details are presented for a 40levels building, along with the other structural responses, in short.

\subsection{FRAMED STRUCTURE 40 levels}

Following the modal analysis with a response range, the following responses resulted for the first four vibration modes:

Table 6. Responses resulted for the first four vibration modes.

\begin{tabular}{|c|c|c|c|c|c|c|c|c|}
\hline \multirow{2}{*}{ Mode } & \multicolumn{4}{|c|}{ Structure without TMD } & \multicolumn{4}{c|}{ Structure with TMD } \\
\cline { 2 - 9 } & Period & $\mathbf{U x}$ & $\mathbf{U y}$ & $\mathbf{R z}$ & Period & $\mathbf{U x}$ & $\mathbf{U y}$ & $\mathbf{R z}$ \\
\hline 1 & 2.769 & 0 & 0.8001 & 0 & 3.398 & 0 & 0.4197 & 0 \\
\hline 2 & 2.62 & 0.8102 & 0 & 0 & 3.312 & 0.3573 & 0 & 0 \\
\hline 3 & 2.333 & 0 & 0 & 0.8274 & 2.457 & 0 & 0.3916 & 0 \\
\hline 4 & 0.895 & 0 & 0.1167 & 0 & 2.384 & 0.4633 & 0 & 0 \\
\hline
\end{tabular}

Note that, when the TMD is mounted, the periods increase, and the placement of masses is fundamentally changed. Thus: 
ROMANIAN JOURNAL

OF TRANSPORT INFRASTRUCTURE

RECE Laurentiu, EZZAKI Naima, STOICA Daniel, JEFLEA Victor Florin

The use of tuned mass dampers for reducing structural vulnerabilities during the side movements of buildings with reinforced concrete frames

In the first case (without TMD) on modules 1 and 2 the mass participation factor was $80 \%$, the result being high seismic forces; After mounting the TMD, these factors of mass participation are divided into two and distributed on 2 modules each, on each main direction. The general torsion phenomenon "decreases" beyond module 4.

If the movements are analyzed, significant drift decreases can be noted - an average of $20 \%$ along the axes X and Y, both for the SLS and the ULS, as shown in the diagrams below:

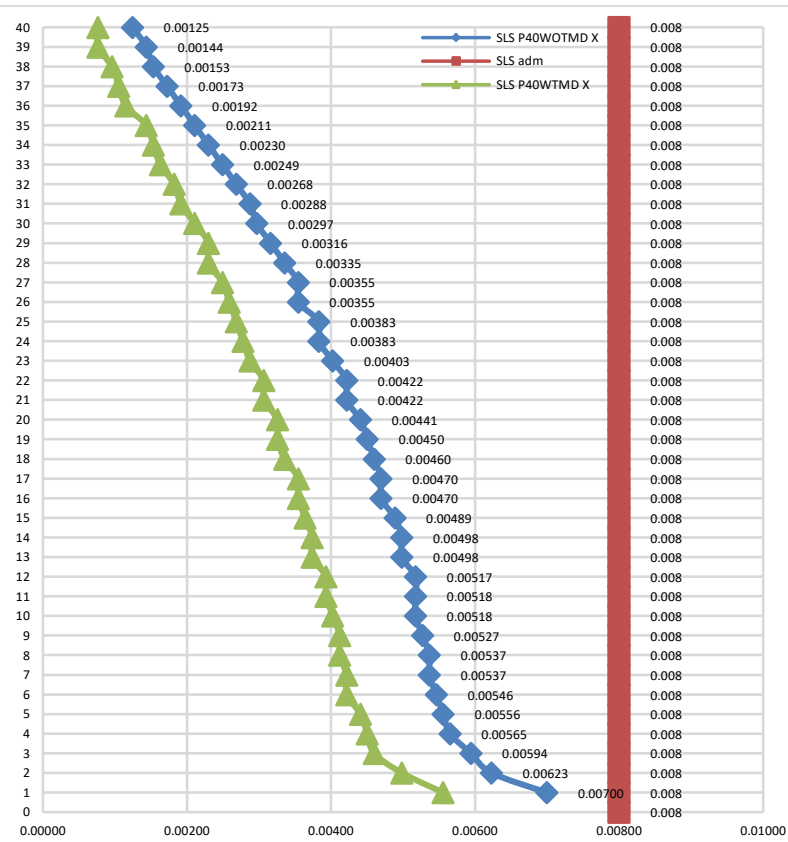

Figure 12 Relative displacements in direction X to SLS

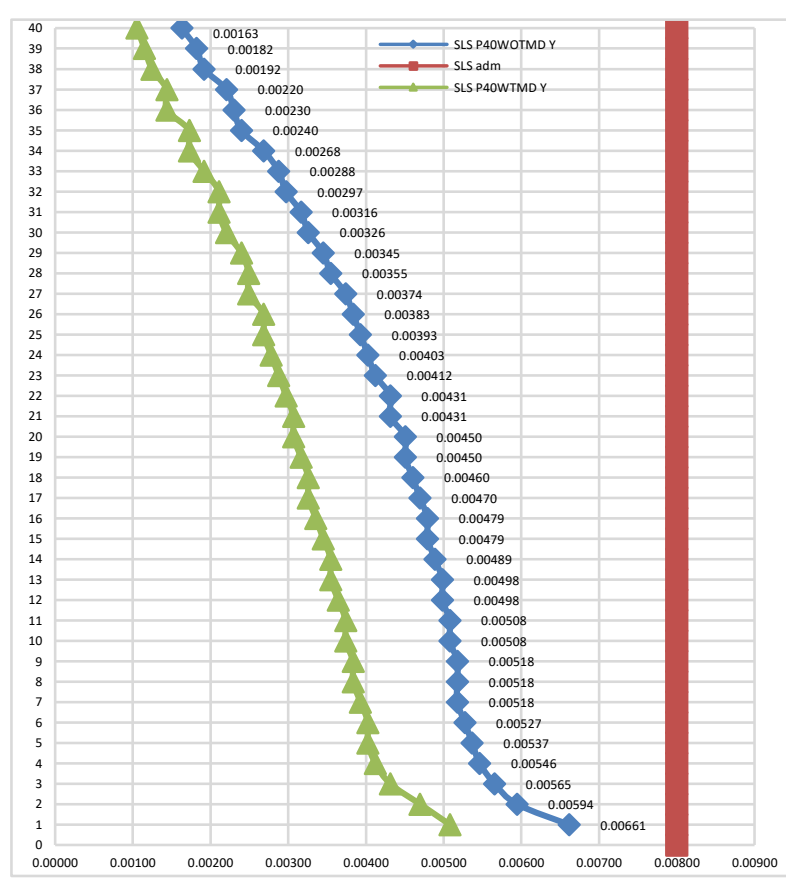

Figure 13.Relative displacements in direction Y to SLS

In order to point out the TMD behavior and its effect in reducing stresses in the components, the following were selected:

A marginal column-named C19; An inner column-named C15; A beam-named B2.

A decrease of the stresses in components can be noted:

In the marginal column $\mathrm{C} 19$ the axial stress decreased on average by $5 \%$, and the bending moment decreased on average by $25 \%$; 
ROMANIAN JOURNAL

OF TRANSPORT INFRASTRUCTURE

RECE Laurentiu, EZZAKI Naima, STOICA Daniel, JEFLEA Victor Florin

The use of tuned mass dampers for reducing structural vulnerabilities during the side movements of buildings with reinforced concrete frames

In the inner column C15 the axial stress decreased on average by $8 \%$ and the bending moment decreased on average by $25 \%$

In the left-hand support of the beam $B 2$ the bending moments decreased on average by $25 \%$, while in the right-hand support they decreased on average by $30 \%$.

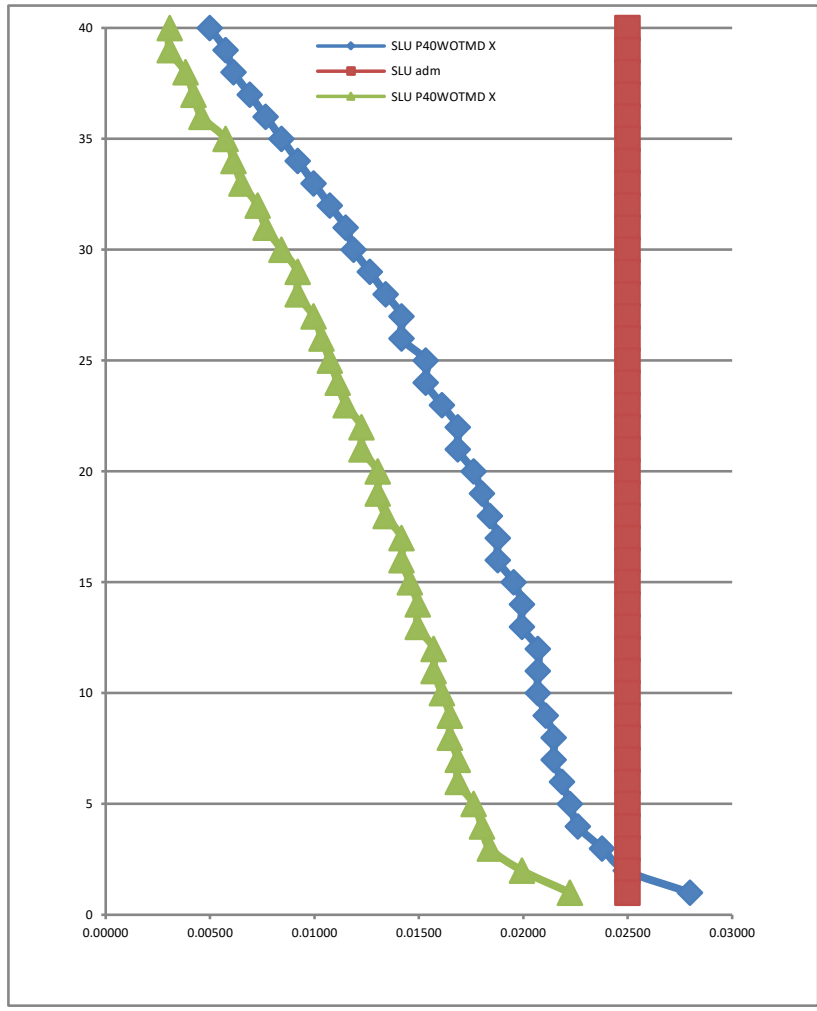

Figure 14Relative displacements in directionX to ULS

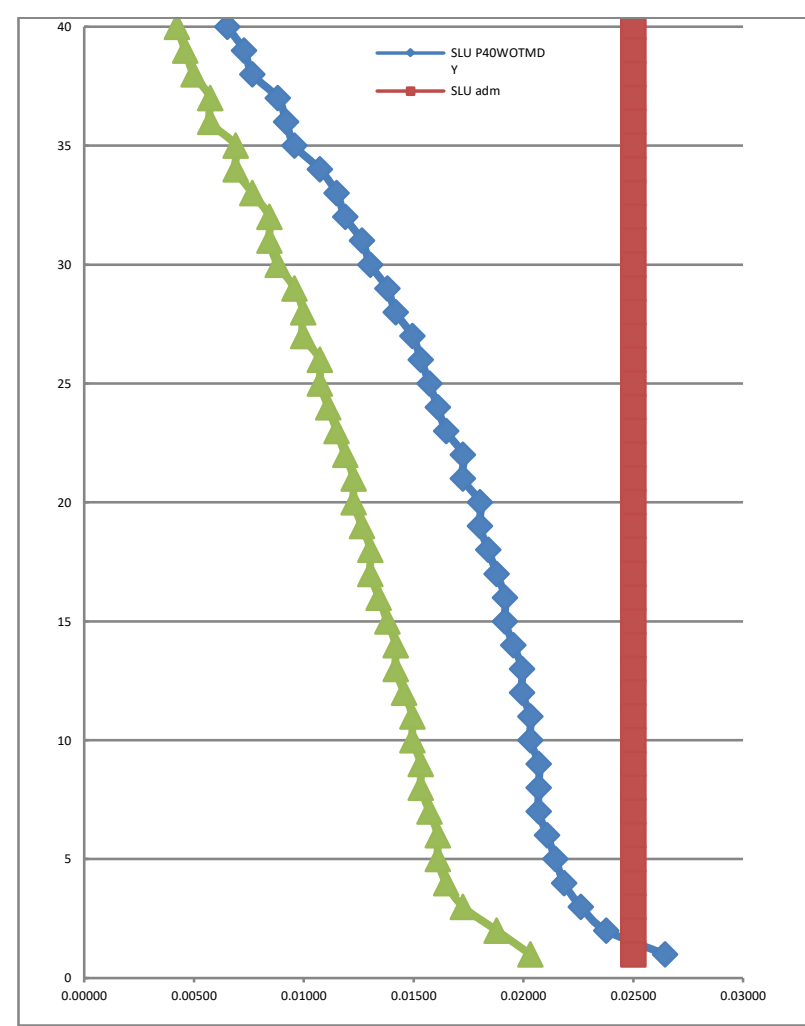

Figure 15Relative displacements on $\mathrm{Y}$ direction to ULS 
ROMANIAN JOURNAL

OF TRANSPORT INFRASTRUCTURE

RECE Laurentiu, EZZAKI Naima, STOICA Daniel, JEFLEA Victor Florin

The use of tuned mass dampers for reducing structural vulnerabilities during the side movements of buildings with reinforced concrete frames

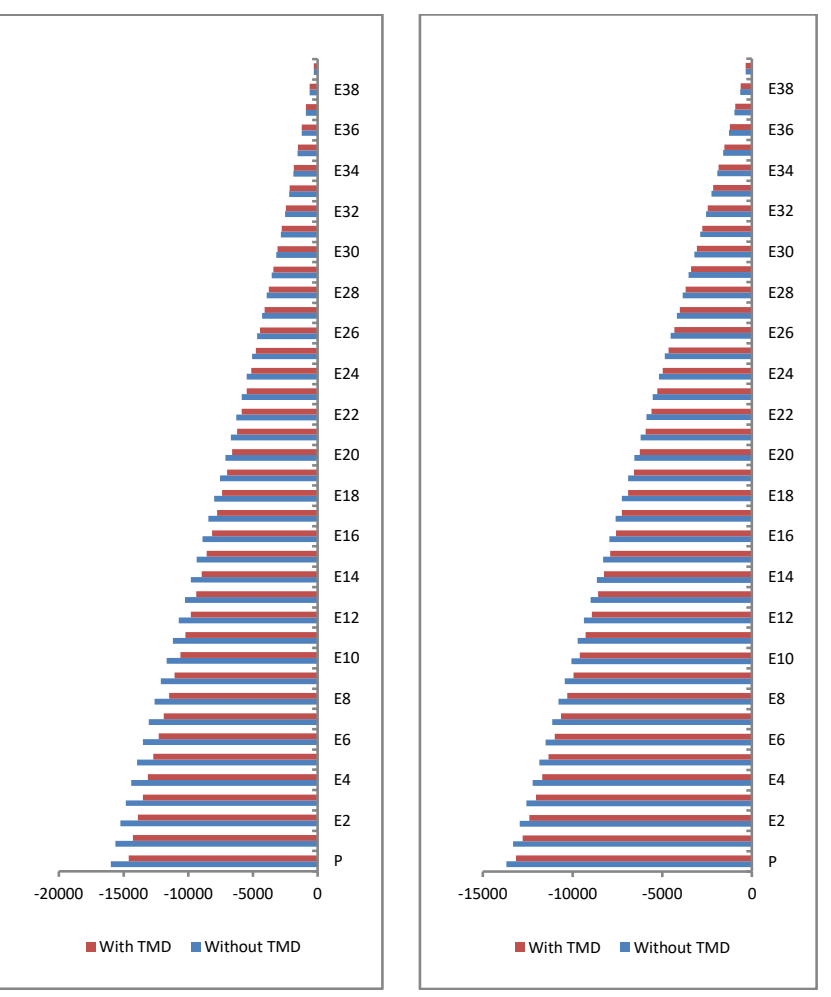

Figure 16Comparison of axial forces for different columns

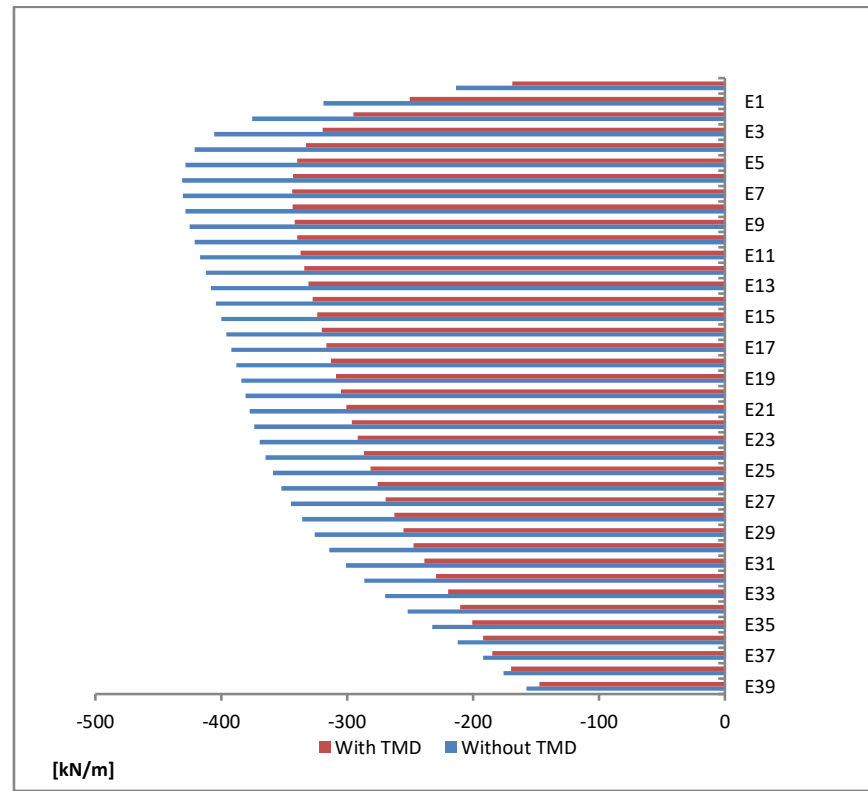

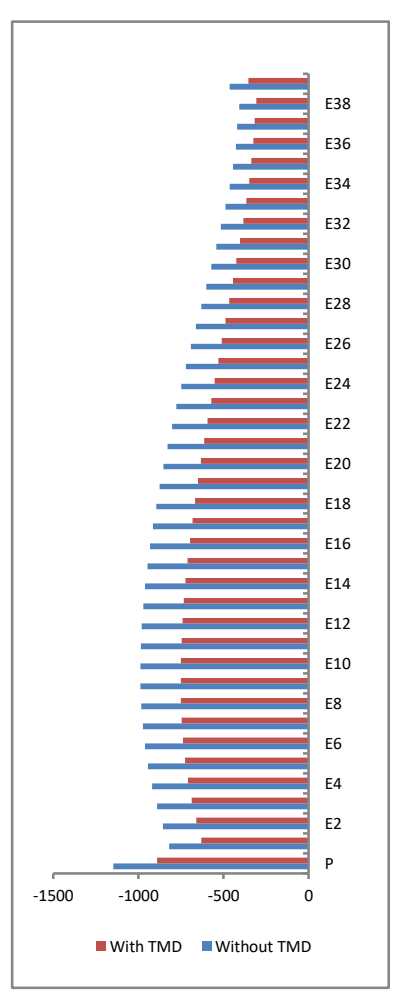

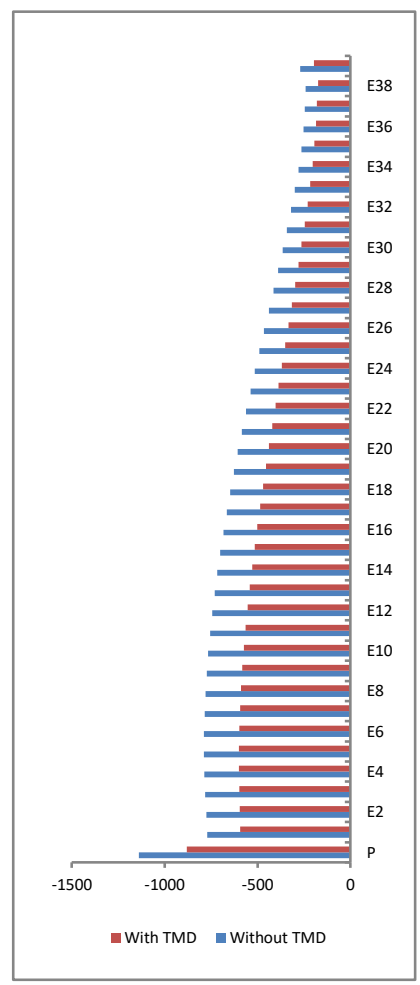

Figure 17. Comparison of bending moments for different columns

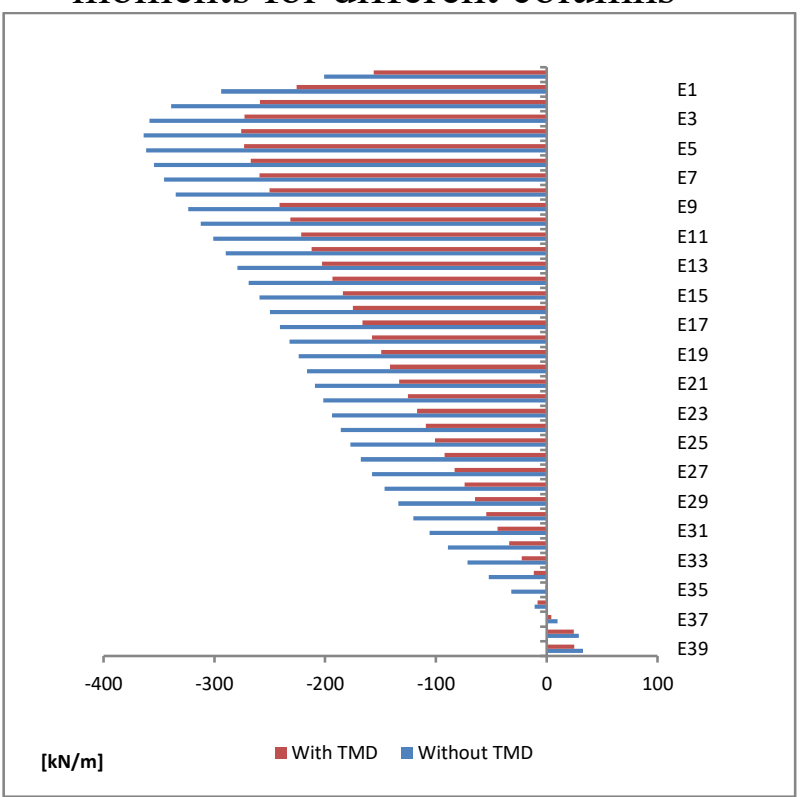

Figure 18Comparison of bending moment for one beam

\subsection{FRAMED STRUCTURE 30 LEVELS}

Following the modal analysis with a response range the following periods resulted for the first four vibration modes: 
ROMANIAN JOURNAL

OF TRANSPORT INFRASTRUCTURE

RECE Laurentiu, EZZAKI Naima, STOICA Daniel, JEFLEA Victor Florin

The use of tuned mass dampers for reducing structural vulnerabilities during the side movements of buildings with reinforced concrete frames

Table 7. Modal analysis with a response range resulted for the first four vibration modes

\begin{tabular}{|c|c|c|c|c|c|c|c|c|}
\hline \multirow{2}{*}{ Mode } & \multicolumn{4}{|c|}{ Structure without TMD } & \multicolumn{4}{c|}{ Structure with TMD } \\
\cline { 2 - 9 } & Period & Ux & Uy & Rz & Period & Ux & Uy & Rz \\
\hline 1 & 1.872 & 0 & 0.7629 & 0 & 2.589 & 0 & 0.4573 & 0 \\
\hline 2 & 1.793 & 0.7693 & 0 & 0 & 2.531 & 0.4279 & 0 & 0 \\
\hline 3 & 1.623 & 0 & 0 & 0.7789 & 1.623 & 0 & 0 & 0.7789 \\
\hline 4 & 0.597 & 0 & 0.1077 & 0 & 1.58 & 0 & 0.3334 & 0 \\
\hline
\end{tabular}

Note that, when the TMD is mounted, the periods increase, and the placement of masses is fundamentally changed. Thus:

In the first case (without TMD) on module 1 the mass participation factor was $76.29 \%$, while on module 2 the mass participation factor was $76.93 \%$;

After mounting the TMD, these factors of mass participation are divided into two and distributed on 2 modules each, on each main direction. The general torsion phenomenon "decreases" beyond module 4.

If the movements are analyzed, significant drift decreases can be noted - an average of $20 \%$ along the axes X and Y, both for the SLS and the ULS.

In order to point out the TMD behavior and its effect in reducing stresses in the components, the following were selected: A corner column - named C32; A marginal column - named C19; An inner column-named C15; A beam-named B20.

A decrease of the stresses in components can be noted:

In the corner column C32 the axial force decreased on average by $8 \%$, and the bending moment decreased on average by $20 \%$;

In the marginal column $\mathrm{C} 19$ the axial stress decreased on average by $5 \%$, and the bending moment decreased on average by $25 \%$;

In the inner column C15 the axial stress decreased on average by 5\% and the bending moment decreased on average by $18 \%$

In the supports of beam B20 the bending moments decreased on average by $25 \%$.

\subsection{FRAMED STRUCTURE 20 levels}

Following the modal analysis with a response range the following periods resulted for the first four vibration modes:

Table 8. Modal analysis with a response range resulted for the first four vibration modes. 
ROMANIAN JOURNAL

OF TRANSPORT INFRASTRUCTURE

RECE Laurentiu, EZZAKI Naima, STOICA Daniel , JEFLEA Victor Florin

The use of tuned mass dampers for reducing structural vulnerabilities during the side movements of buildings with reinforced concrete frames

\begin{tabular}{|c|c|c|c|c|c|c|c|c|}
\hline \multirow{2}{*}{ Mode } & \multicolumn{4}{|c|}{ Structure without TMD } & \multicolumn{4}{c|}{ Structure with TMD } \\
\cline { 2 - 9 } & Period & $\mathbf{U x}$ & $\mathbf{U y}$ & $\mathbf{R z}$ & Period & $\mathbf{U x}$ & $\mathbf{U y}$ & $\mathbf{R z}$ \\
\hline 1 & 1.477 & 0 & 0.7694 & 0 & 2.05 & 0 & 0.4768 & 0 \\
\hline 2 & 1.434 & 0.7726 & 0 & 0 & 2.018 & 0.457 & 0 & 0 \\
\hline 3 & 1.323 & 0 & 0 & 0.7761 & 1.323 & 0 & 0 & 0.7761 \\
\hline 4 & 0.469 & 0 & 0.1009 & 0 & 1.237 & 0 & 0.3217 & 0 \\
\hline
\end{tabular}

Note that, when the TMD is mounted, the periods increase, and the placement of masses is fundamentally changed. Thus:

In the first case (without TMD) on modules 1 and 2 the mass participation factors were $76.47 \%$ and $77.26 \%$ resulting in high seismic forces After mounting the TMD, these factors of mass participation are divided into two and distributed on 2 modules each, on each main direction. The general torsion phenomenon "decreases" beyond module 4.

If the movements are analyzed, significant drift decreases can be noted - an average of $20 \%$ along the axes X and Y, both for the SLS and the ULS.

In order to point out the TMD behavior and its effect in reducing stresses in the components, the following were selected: A corner column-named C32; A marginal column - named C19; An inner column - named C12; A beam-named B20.

A decrease of the stresses in components can be noted:

In the corner column C32 the axial force decreased on average by $7 \%$, and the bending moment decreased on average by $10 \%$;

In the marginal column $C 19$ the axial stress decreased on average by $6 \%$, and the bending moment decreased on average by $20 \%$;

In the inner column C12 the axial stress decreased on average by $4 \%$ and the bending moment decreased on average by $15 \%$

In the supports of beam B20 the bending moments decreased on average by $10 \%$.

\subsection{FRAMED STRUCTURE 10 LEVELS}

Following the modal analysis with a response range the following periods resulted for the first four vibration modes:

Table 9. Modal analysis with a response range resulted for the first four vibration modes: 
ROMANIAN JOURNAL

OF TRANSPORT INFRASTRUCTURE

RECE Laurentiu, EZZAKI Naima, STOICA Daniel, JEFLEA Victor Florin

The use of tuned mass dampers for reducing structural vulnerabilities during the side movements of buildings with reinforced concrete frames

\begin{tabular}{|c|c|c|c|c|c|c|c|c|}
\hline \multirow{2}{*}{ Mode } & \multicolumn{4}{|c|}{ Structure without TMD } & \multicolumn{3}{c|}{ Structure with TMD } \\
\cline { 2 - 9 } & Period & Ux & Uy & Rz & Period & Ux & Uy & Rz \\
\hline 1 & 0.745 & 0 & 0.7748 & 0 & 1.033 & 0 & 0.5006 & 0 \\
\hline 2 & 0.728 & 0.7769 & 0 & 0 & 1.021 & 0.4859 & 0 & 0 \\
\hline 3 & 0.678 & 0 & 0 & 71.0368 & 0.678 & 0 & 0 & 0 \\
\hline 4 & 0.23 & 0 & 0.1036 & 0 & 0.615 & 0 & 0.3046 & 0 \\
\hline
\end{tabular}

Note that, when the TMD is mounted, the periods increase, and the placement of masses is fundamentally changed. Thus:

In the first case (without TMD) on modules 1 and 2 the mass participation factors were $77.48 \%$ and $77.69 \%$ resulting in high seismic forces.

After mounting the TMD, these factors of mass participation are divided into two and distributed on 2 modules each, on each main direction. The general torsion phenomenon "decreases" beyond module 4.

If the movements are analyzed, significant drift decreases can be noted - an average of $2 \%$ along the axes X and $\mathrm{Y}$ for the SLS and 1.5\% for the ULS.

From the point of view of movement reduction, the use of TMD for the $\mathrm{P}+10 \mathrm{E}$ is not justified, the solution is not applicable.

In order to point out the TMD behavior and its effect in reducing stresses in the components, the following were selected: A corner column - named C32; A marginal column - named C19; An inner column - named C12 ;A beam-named B20.

A decrease of the stresses in components can be noted:

In the corner column C32 the axial force decreased on average by $1 \%$, and the bending moment decreased on average by $2 \%$;

In the marginal column $\mathrm{C} 19$ the axial stress decreased on average by $1 \%$, and the bending moment decreased on average by $2 \%$;

In the inner column C12 the axial stress decreased on average by $2 \%$ and the bending moment decreased on average by $4 \%$

In the supports of beam B20 the bending moments decreased on average by $10 \%$.

\section{CONCLUSIONS}

We noted that by adding TMDs the initial participation factors of around $75 \%$ for translation on $\mathrm{x}$ (mode 1), translation on $\mathrm{y}$ (mode 2) and torsion (mode 3 ) are significantly modified: both module 1 and 2 become translations on $\mathrm{x}$, with mass participation factors of $37.5 \%$; modules 2 and 4 become translations on y with mass participation factors of $37.5 \%$ (all being pure translations, without torsion), while modules 5 and 6 become torsion modes with mass participation factors of $37.5 \%$. 


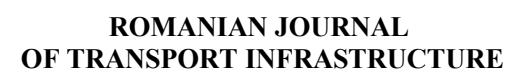

RECE Laurentiu, EZZAKI Naima, STOICA Daniel , JEFLEA Victor Florin

The use of tuned mass dampers for reducing structural vulnerabilities during the side movements of buildings with reinforced concrete frames

We also noted an increase by 1.4 times of the vibration periods, for the basic vibration modes.

Following the dynamic linear analysis with a response range for all the structures in the two cases mentioned, the following general conclusions were drawn. They are divided below as advantages and disadvantages:

\section{Advantages:}

A relatively simple mechanism and easy to make;

Higher reliability resulting from its simplicity;

Relative movements per level decrease on average by around 25\%;

Axial stresses in columns and/or structural reinforced concrete walls are reduced by about $5 \%$;

The bending moments in columns decreased by about $20 \%$;

The bending moments in structural reinforced concrete walls decreased by about $10 \%$;

The bending moments in beam supports decreased by around $25 \%$;

Increased damping of structural system oscillations;

Easy computation of TMD characteristics;

In general, they are efficient for buildings with a medium and great height regime.

\section{Disadvantages:}

Local load of structural elements with significant gravitational forces;

The linking system to the structure must be designed in order to distribute the load on as many structural elements as possible, so as not to determine major, concentrated local effects;

Problems arise when the pendulum is longer than the level height and when enough empty space must be provided for its oscillation;

They are not efficient for low-rise buildings.

\section{REFERENCES}

[1]. SHAO D., PALL A., SOLI B. Friction Dampers for Seismic Upgrade of a 14-story Patient Tower With a 36-foot Tall Soft-story; http://www.palldynamics.com/pdf/Paper00901.pdf

[2]. KOURAKIS, I.Structural Systems and Tuned Mass Dampers of Super-Tall Buildings: Case Study of Taipei 101. Cambridge, SUA:MIT- Thesis, 


\section{ROMANIAN JOURNAL \\ OF TRANSPORT INFRASTRUCTURE}

RECE Laurentiu, EZZAKI Naima, STOICA Daniel , JEFLEA Victor Florin

The use of tuned mass dampers for reducing structural vulnerabilities during the side movements of buildings with reinforced concrete frames

http://dspace.mit.edu/bitstream/handle/1721.1/38947/166269711.pdf?sequence=1 , 2007

[3]. TAYLOR D., DUFLOT P. Fluid Viscous Dampers Used for Seismic Energy Dissipation in Structures; http://www.taylordevices.eu/pdfs/seismic\%20applications.pdf.

[4]. HUSSAIN S., AL SATARI M., Design of a Seismic Isolation System with Supplemental Viscous Damping for a Near-Fault Essential Services Facility. SEAOC 2007 Convention Proceedings, http://www.coffman.com/documents/news/industry articles/la 2008/2007seaoclartmccoff man.pdf, 2007.

[5]. EZZAKI, N. Contributions regarding the consolidation of existing buildings using solutions with steel elements, $\mathrm{PhD}$ report (2018).

[6]. V FLORESCU, L RECE, Ș MOCANU, A LEGENDI, Comparative Study on the Applicability of Analytical and Experimental Methods in the Analysis of the Safe Use of Rail Tankers Carrying Petroleum Products Under Pressure, Romanian Journal of Transport Infrastructure 7 (1), 107-116, (2018)

[7]. P100-3:2008 Code for evaluation and design of consolidation works on existing, seismically vulnerable buildings

[8]. P100-1:2013 Design provisions for buildings

[9]. P13-63 Conditional normative for the design of civil and industrial buildings in seismic regions 